of vertebrate teratology recently studied by him, and Prof. A. B. Macallum, F.R.S., described some new cells with protruding tail-like processes occurring in the mesogloea of Aurelia and other Medusæ.

The popular evening lecture, which is always an important feature of the Canadian Royal Society's annual meeting, was delivered to a crowded assembly in the large hall of the Normal School by Prof. Ernest Rutherford. The subject was " Recent Results of Researches on Radium." In a graphic manner, the lecturer explained his famous "disintegration" theory, the transformation of chemical elements, the marvellous phenomena of radiant matter, and illustrated his remarks by striking experiments. $\mathrm{He}$ aroused much interest by stating that in Canada there were probably more rocks containing radium than in any other territory on the globe, and he had found, by suspending a wire in the open air in Montreal during a shower of rain, that radium collected on the wire. Many brilliant social functions took place during the meetings, including a large garden party by Dr. and Mrs. Saunders at their official residence; dinners given by the president-elect, Dr. S. E. Dawson; luncheons by Sir James Grant, former president; and other entertainments.

\section{THE ROYAL VISIT TO THE UNIVERSITY COLLEGE OF NORTH WALES.}

I N last week's NaTURE, a short account was given of the voundation the King and Dane of Bangor to lay the College of Aorth origin and Work df the college, and forne thoughts suggested appeared.

The Universify opllef of North Wales was founded in r884, and is at pesent located in the buildings of the former Penrhyn Arms Hotel. It has been enlarged by the addition of labotatories and lecture rooms for the faculty of science, which includes departments of agriculture and electrical engineering. 'The former was the first institution of its kind in Great Britain, and has been adopted as the model of similar agricultural departments started elsewhere. Its operations have been extended by the foundation in 1904 of a school of forestry under the auspices of the Board of Agriculture, one of two in the United Kingdom. The electrical engineering department is maintained by an annulal grant from the Drapers' Company. If its resources in the matter of equipment have not been on a lavish scale, the training it has afforded has been of a high character and has probably possessed advantages which an overelaborate plant might not afford. Still, much apparatus is badly needed before the condition of maximum efficiency can be reached. Another feature is the fisheries department, which has performed useful work in developing the fishing industry of North Wales, an industry which is capable of being greatly developed by the diffusion of practical scientific knowledge in the fishing districts. Although the present notice necessarily deals primarily with the scientific aspect of the work of the college, allusion must be made to the day training department, the courses in secondary education, and the facilities for kindergarten training afforded by the establishment of a preparatory school under the auspices of the college.

The new college will consist, when finished, of two quadrangles. At present it is only intended to erect the arts and administrative buildings, and it is to be hoped that by the time this has been done the building fund will admit of the science buildings being commenced. The library is very inadequately housed, and when we point out that only about rol. a year is available for the purchase of books in such a subject as pure and applied mathematics combined, physics or chemistry, it will be seen that the present college staff is doing good work under difficulties which would not exist in a similar institution in Germany or America.

At the public luncheon, the Right Hon. D. Lloyd George, M.P., gave some interesting statistics showing the liberality and enthusiasm of the people of North Wales in matters relating to education. The contributions for uni- versity and technical education are six times, and to secondary education nine times, as high as in England, and the contributions of the town and suburbs of Bangor to the college alone represent the proportional equivalent of a sum which for a town of the size of Liverpool and its suburbs works out to $1,750,000 l$. In regard to the question of Government assistance, Mr. Lloyd George thought that waiting for Governments was like waiting for sunshine, and that the college afforded a grand opportunity for a millionaire to earn gratitude and fame.

But where is Mr. Lloyd George going to find his millionaire? A country which raises a protective tariff against millionaires in the form of death duties is scarcely a promising field. When we take account of the heavy losses North Wales has sustained by the death of a number of its most influential and prominent landowners during the last decade, the progress of the new college buildings will be found to represent a widespread feeling of munificence and loyalty towards the cause of higher national education far in advance of anything that exists in America. But in the race between British and American universities, Great Britain is heavily handicapped, with the result that, in spite of all the efforts we are putting forward, we are rapidly falling further and further behind. The inevitable result is that the responsibilities which the acquisition of wealth entails will be pressed more and more heavily every year on our Governments, and unless they can supply the extra few rays of sunshine we shall be less and less able every year to raise up the intellectual produce necessary to enable us to compete with the foreign producer.

The problem was solved long ago for Germany by her system of State universities. That Germany owes her national prosperity in no small measure to the principle of Lehrfreiheit, which has been adopted as the fundamental law governing the relations of the university professors with the State, is a fact which every German citizen knows well. It is no trifling thing to say that there is probably not a single university college in the United Kingdom the council and senate of which are more thoroughly imbued with the spirit of the German ideal than the University College of North Wales. In the large industrial centres of South Wales there exists an unfortunate conflict of rival factions, and it is sad to notice that many people only assciciate themselves with university education in order to acquire a cheap reputation by belittling the academic element, making unjustified and vexatious attacks on its representatives, and hampering the progress of the nation whose interests they falsely profess to have at heart. We refer in particular to the state of affairs which culminated some years ago in the premature death of the late Principal Viriamu Jones, and has continued to exist ever since. In North Wales the ardent Welsh nationalist, and the scientific worker who believes that "he is the greatest patriot who has the world for his nation," all realise that they are working together for a common cause.

G. H. Bryan.

\section{THE ALDROVANDI CELEBRATIONS AT BOL.OGNA,}

$\mathrm{T}^{\mathrm{T}}$ is not improbable that some of delegates appointed to represent foreign universins and learned societies at the tercegtenary of thop ceath of Ulisse Aldrovand $(1522-1607)$ ore insy nortly acquainted with the works of this greft tafupalist to appreciate thoroughly the importance of the occasion. The international gathering at Bologne (Jine $11-13$ ) has been the means of rescuing from parhal obscurity the memory of one of the many pioneers in the study of nature which Italy has produced. Bologna, the birthplace of universities and the alma mater of not a few students whose names occupy a prominent place in the history of the natural sciences, is an ideal meeting place of the nations to do homage to one of the fathers of scientific investigation. The numerous coats of arms which decorate the walls of the old university buildings bear witness to the hospitality of Bologna to students from all parts of the world, and the celebration which has now been brought to a successful conclusion testifies to the continuance of a spirit of hospitality after the lapse of centuries. 